\title{
Glioblastoma in 140 characters
}

Nimish A. Mohile, MD

Neurology ${ }^{\circledR}$ 2018;90:803-804. doi:10.1212/WNL.0000000000005348

\section{Wednesday July 19th, 9 PM EST}

At home, on my laptop, logged in to eRecord, working on my clinic notes (we have a 72-hour deadline), I receive a ping on my phone: a news alert from the Washington Post. I gladly step away from clicking on diagnosis codes: "Senator John McCain has brain cancer." As a neurooncologist, I suspect this will turn out to be glioblastoma. Media reports in the next 24 hours would both startle and distress my patients and their families. \#28notesleft

\section{Wednesday July 19th, 9:42 PM EST}

Down to 24. I hear a swoosh. An email from the marketing team at my institution asks me to do TV and radio interviews to shed light on Senator McCain's diagnosis. I say yes because I have to but I'm disappointed that I will have to wear a tie on an academic day. I sleep. \#24notes

\section{Thursday July 20th, 8:15 AM EST}

I gather with colleagues at our multidisciplinary tumor board and the conversation is about last night's news. We express outrage at media disinformation. To be clear, glioblastoma is not surgically curable, is not related to melanoma, and is not found on a routine physical examination. All of our patients are fighters and almost all of them still die. \#cancersucks

\section{Thursday July 20th, 9:15 AM EST}

I log on to the New York Times website instead of eRecord. The Times, as usual, has an article that is accurate, quotes true medical experts, gives sufficient background, and is measured. I check the Wall Street Journal, find a similar article, and confirm that these are not articles tainted by liberal or conservative bias. \#still24notes \#NYTisNotFailing

\section{Thursday July 21st, 9:33 AM EST}

I log on to eRecord but I entered the wrong password. I try again and work on 5 more notes, then I log on to Facebook. I don't friend patients, but over the years I have friended several family members of deceased patients. They are all posting about the news. This is hard for them and it reminds them of the devastating days after their loved one's diagnosis. People have tough lives. \#19notesleft \#cancercaregivers

\section{Thursday July 21st, 10:00 AM EST}

I meet with the first local news team. Their agenda is to bring in a local element to a national story. The institution's agenda is marketing. I try to use the terms precision medicine, immunotherapy, and targeted agent at least once in each interview. My primary agenda is to avoid saying something to upset or confuse my patients but I also want to find out when I will be on TV, so I can tell my mom. My kids don't care. \#still19notes \#proudmoms

\section{Thursday July 21st, 11:00 AM EST}

Interview number 2. The anchor tells me to avoid using medical and scientific jargon. "Talk as if you are speaking with your patients.” THIS IS NOTHING LIKE SPEAKING WITH YOUR PATIENTS. We don't talk in sound bites. Discussing a new diagnosis of a glioblastoma can take hours and often occurs over several visits. As neuro-oncologists, we learn to tailor that

\author{
Correspondence \\ Dr. Mohile \\ Nimish_mohile@urmc. \\ rochester.edu
}

MORE ONLINE

\section{ค Audio}

Listen to Dr. Mohile read

this story

NPub.org/o4awtx 
conversation to our patient's and family's education level to assess their understanding, look for cues, and to assess their emotional reaction. Every conversation is different. He asks the question I dread: "How long do you think Senator McCain will live?" John McCain has a glioblastoma and he has to listen to the whole world talk about his mortality. I speak broadly, but I have a second fear that I am ashamed to admit. I know that some of my patients don't truly understand their mortality, and I don't want this to be the way they hear it from me.\#still19 \#donotjudgeme

\section{Thursday July 21st, 12:00 PM EST}

Interview number 3 . She advises me to make all statements brief and to the point. "Like, when you are on twitter." I picture myself tweeting to my patients: Path is GBM. Survival 14 months. RT + Chemo. Do a clinical trial. Taper dex. SAD! I could attach a Kaplan-Meier survival curve and not exceed the 140 character limit. And I would have more time for notes. \#noprogresswithnotes \#writeshorternotes

\section{Thursday July 21st, 1:00 PM EST}

The last anchor wants to shoot extra footage or "b-roll." I have no patients today so we decide to get film of me doing what I really do all day-sit at a computer. She asks me to scroll through an MRI because it appears more interesting than clicking "Mark as reviewed" on eRecord. I actually get 1 note done during the "b-roll" footage. A patient advice request comes in to my eRecord inbox. It is from a patient with a recent diagnosis of a low-grade glioma. He is looking for results of his molecular testing. I want to respond: Great news! IDH1 mutation, 1p/19q codeletion. Survival good. \#18notes \#biomarkers

\section{Thursday July 21st, 2:00 PM EST}

This is the last interview and it is with our local National Public Radio affiliate. It is on a landline phone. Our marketing person reassures me prior to my interview: "You have a voice for radio." She did not tell me I have a face for TV. The interview is casual and feels like a conversation. I can convey information that is accurate, nuanced, and scientific. \#still18notes \#NPRRocks

\section{Thursday July 22nd, 3:00 PM EST}

I am back on eRecord to write notes but see a phone call. "I saw Dr. Mohile on TV at noon and he said there were new promising immunotherapies for my tumor. Why am I not getting them?" The patient is on a clinical trial and receiving an experimental vaccine. My fantasy tweet: Your vaccine study = immunotherapy. Last MRI stable. Hang in there! I address phone calls, results, copied notes, staff messages, treatment renewal requests, patient advice requests, cosign chemo orders, and finally finish 6 more notes. \#12notes \#notfeelingEpic

\section{Thursday July 22nd, 5:30 PM EST}

One more phone call. A GBM patient on a dexamethasone taper with worsening aphasia and headaches. I send my nurse a tweet replete with prohibited abbreviations: Increase dex to 4 bid, then taper by $1 \mathrm{mg}$ qWeek. I muse about how Thursday is my academic day and I have accomplished nothing. \#12notesleft \#IsThisBurnout \#sofrustrating

\section{Thursday July 22nd, 9:00 PM EST}

The kids are asleep, U2 is playing, and my wife opens a bottle of our new favorite white wine, discovered on a recent trip to Italy. A well-deserved, relaxing summer night. My wife, also a physician, and I are both on our laptops, writing notes. We share tips about how to most efficiently document review of systems. \#8notes \#loveisintheair

\section{Friday July 23rd, 8 AM EST}

The 72-hour note deadline is today. There is a patient message on eRecord. A glioblastoma patient with epilepsy had a breakthrough generalized tonic-clonic seizure and is back to baseline. Increase Keppra to 1,000 twice a day. No driving. Recent MRI stable. Will make clinic appt next week. OMG! THAT WAS NOT A FANTASY TWEET THAT WAS MY REAL RESPONSE! Am I communicating with my patients or am I tweeting to them? \#only8notesleft \#talktoyourpatients

\section{Friday July 23rd, 9 AM EST}

Grand rounds or finish notes? I go to grand rounds. I learn that neurologists listen to NPR in the morning on their way to work. \#8painfulnotes \#anythingbutnotes \#CMEforMOC

\section{Friday July 23rd, 11 AM EST}

Time to sit down and finish these damn notes. Now a text page from the triage nurse: pls check urgent eRecord message from patient very upset. I log on and see a patient advice request: "Dr. Mohile, I saw you on the news last night and you said there have been 4 new drugs approved for glioblastoma in the past 10 years. I had temodar and avastin and at the last visit, you told me there were no more proven drugs. Is there something else? I am really anxious about this. Please call me right away.” I didn't say there were 4 new drugs because it is not true, but to my patient's credit, the news anchor did. This will no doubt require a phone call but I can't help but fantasize about the tweet: The FAILING media is lying to you about GBM. Don't believe the FAKE news! I call her and we talk for 20 minutes. She feels better and I feel rewarded that she has come to a better understanding of her disease. A highlight in my week. IS THIS THE FIRST REAL CONVERSATION I'VE HAD WITH A PATIENT IN THE LAST 2 DAYS? I briefly contemplate what it means to be a physician today. Address angst about my job or finish my notes? For once, my notes win.\#NotesDone \#BurnoutAverted \#ExistentialCrisisDeferred 


\section{Neurology}

\section{Glioblastoma in 140 characters}

Nimish A. Mohile

Neurology 2018;90;803-804

DOI 10.1212/WNL.0000000000005348

\section{This information is current as of April 23, 2018}

\section{Updated Information \&} Services

\section{Subspecialty Collections}

Permissions \& Licensing

\section{Reprints}

including high resolution figures, can be found at: http://n.neurology.org/content/90/17/803.full

This article, along with others on similar topics, appears in the following collection(s):

Primary brain tumor

http://n.neurology.org/cgi/collection/primary_brain_tumor

Information about reproducing this article in parts (figures,tables) or in its entirety can be found online at:

http://www.neurology.org/about/about_the_journal\#permissions

Information about ordering reprints can be found online:

http://n.neurology.org/subscribers/advertise

Neurology ${ }^{\circledR}$ is the official journal of the American Academy of Neurology. Published continuously since 1951, it is now a weekly with 48 issues per year. Copyright () 2018 American Academy of Neurology. All rights reserved. Print ISSN: 0028-3878. Online ISSN: 1526-632X.

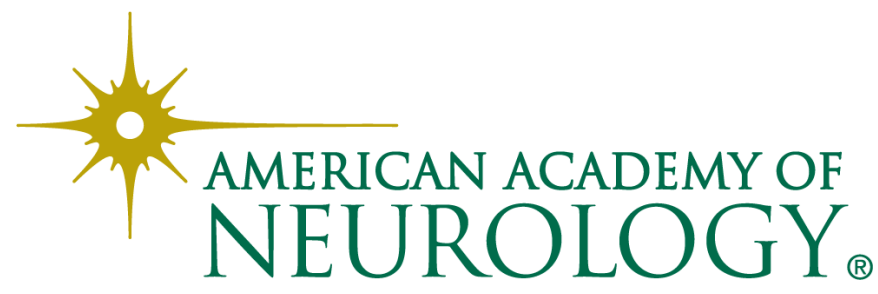

